\title{
Schwannoma of the submandibular region
}

\author{
Submandibüler bölge schwannoması
}

\author{
Sedat Aydın, ${ }^{1}$ Mehmet Gökhan Demir, ${ }^{2}$ Mahmut Ozan Fındık, ${ }^{1}$ Kayhan Başak, ${ }^{3}$ Muhammet Gazi Yıldız \\ ${ }^{1}$ Department of Otolaryngology, Kartal Dr. Lütfi Kırdar Training and Research Hospital, İstanbul Turkey \\ ${ }^{2}$ Department of Otolaryngology, Prof. Dr. Celal Ertŭ̆ Etimesgut State Hospital, Ankara, Turkey \\ ${ }^{3}$ Department of Pathology, Kartal Dr. Lütfi Kırdar Training and Research Hospital, İstanbul Turkey
}

\begin{abstract}
Schwannomas, benign neural sheath tumors, are mostly located at head and neck region on the cranial nerves and sympathetic nerves as solitary lesions. Most of the cases are asymptomatic and can be detected in any age and gender. Imaging modalities such as magnetic resonance imaging and computer tomography may be suggestive for diagnosis but pathologic diagnosis is sometimes difficult with fine needle aspiration biopsy. The treatment modality is surgical excision of the mass via enucleation or total excision. We represent a hypoglossal nerve schwannoma in submandibular region of a 39-year-old female patient who was treated successfully with extracapsular excision without any recurrence during one-year follow-up.
\end{abstract}

Keywords: Head and neck neoplasms; neurilemmoma; schwannoma; submandibular gland; treatment.

Schwannoma is a benign neural sheath tumor with approximately $40 \%$ of cases seen in the head and neck region. ${ }^{[1]}$ Schwannomas can originate from the $4^{\text {th }}, 5^{\text {th }}$,

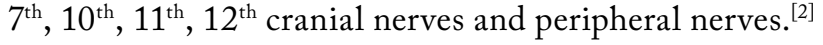
In the head and neck region most affected cranial nerves are the vagus nerve and sympathetic nerves. ${ }^{[3]}$ We present a submandibular schwannoma derived from the hypoglossal nerve that was surgically excised without loss of nerve function.

\section{CASE REPORT}

A 39-year-old female was admitted to the ENT clinic with a complaint of mass gradually growing over the past five years. She did not seek medical advice

\section{$\ddot{O} Z$}

Schwannomalar sinir kılıfı kaynaklı benign tümörler olup çoğunlukla baş ve boyun bölgesinde yerleşik kraniyal sinirler ve sempatik sinirlerden kaynaklanan soliter lezyonlar olarak karşımıza çıkar. Birçok olgu asemptomatik olup her yaş ve her iki cinsiyette tespit edilebilir. Görüntüleme yöntemlerinde manyetik rezonans görüntüleme ve bilgisayarlı tomografi tanıda fikir verebilir ancak ince iğne aspirasyon biyopsisi ile patolojik tanı bazen zordur. Tedavisi enükleasyon veya total eksizyon yoluyla kitlenin cerrahi eksizyonudur. Bu yazıda 39 yaşında bir kadın hastada bir yıllık izlem sırasında herhangi bir nüks olmadan submandibüler bölgede yer alan hipoglossal sinir kaynaklı schwannoma olgusunun ekstrakapsüller eksizyon yöntemi ile cerrahi tedavisi sunuldu.

Anabtar sözcükler: Baş ve boyun tümörleri; nörilemmom; schwannoma; submandibüler bez; tedavi.

because the mass was small and she did not have any other complaints. Because it became bigger in the last year, the patient consulted in different clinics. Fine needle aspiration biopsy (FNAB) of the mass was nondiagnostic, and she was finally referred to our clinic.

The mass did not cause any pain or loss of function. On physical examination, a well-demarcated, solid and rubbery mass was palpated in the left submandibular area. The mass was $5 \times 5 \mathrm{~cm}$ in size and all cranial nerve examinations were intact (Figure 1). The $\mathrm{T}_{2}$ weighted magnetic resonance investigation (MRI) revealed a contrast enhancing sharply demarcated $5 \times 5 \mathrm{~cm}$ leftsided mass (Figure 2a, b). Because the FNAB was not diagnostic, we decided to excise the mass for 


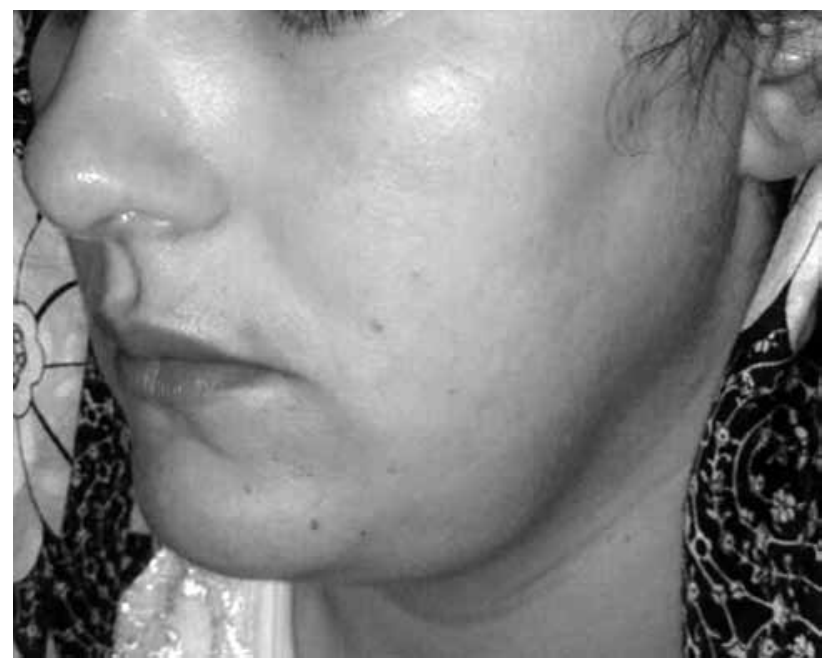

Figure 1. A $5 \times 5 \mathrm{~cm}$ well-demarcated, solid, rubbery left submandibular mass.

pathological evaluation. Extracapsular surgical excision was performed under general anesthesia (Figure 3). The histopathologic diagnosis was schwannoma (Figure 4a, b). There was no recurrence on 18 months of follow-up.

\section{DISCUSSION}

Scwannomas are benign neural sheath tumors that mostly originate from the vagus and sympathetic nerves. Hypoglossal nerve schwannoma is rarely reported in the literature. ${ }^{[4]}$ Our case is one of these rarely described forms of schwannoma.

Most of the cases represent a mass in the head and neck region. Schwannoma may be detected at all ages with peak incidence in the second and third decades of life and has no gender predominance. ${ }^{[5]}$ It can also cause nerve paralysis due to compression. Vagal schwannomas are characterized by dysphagia and hoarseness whereas sympathetic nerve schwannomas present with Horner's syndrome. Hypoglossus nerve schwannomas can present with paralysis of the tongue. ${ }^{[5]}$ Our case had an asymptomatic mass in the submandibular region.

Preoperative investigations such as FNAB are not generally sufficient. Liu et al. ${ }^{[6]}$ emphasized that only $20 \%$ of FNAB investigations were diagnostic. Similarly Yörük et al. ${ }^{[7]}$ reported that fine needle aspiration biopsy did not reveal any diagnostic clues. In our case FNAB examination was also nondiagnostic.

Ultrasonography can be helpful in the diagnosis of schwannoma due to its specific vascular properties ${ }^{[8]}$ but MRI is the most valuable diagnostic method. ${ }^{[9]} \mathrm{T}_{1}$-weighted images show low signal intensity and $\mathrm{T}_{2}$-weighted images show high intensity. ${ }^{[10]}$ Our case had a high intensity well demarcated lesion on $\mathrm{T}_{2}$-weighted image.

The treatment choice for schwannoma is surgical excision via intracapsular enucleation or complete extracapsular tumoral excision. The problem and risk from surgery is nerve paralysis. Previous reports estimated that more than half of patients experience neural deficits. ${ }^{[11]}$ These may be related to poor surgical experience and careless dissection during removal. We preferred extracapsular enucleation in our case. The hypoglossal nerve function was totally preserved after surgery. Other surgical methods such as intracapsular enucleation have been reported as preserving 30\% more neural function. ${ }^{[12]}$ The important point in this technique
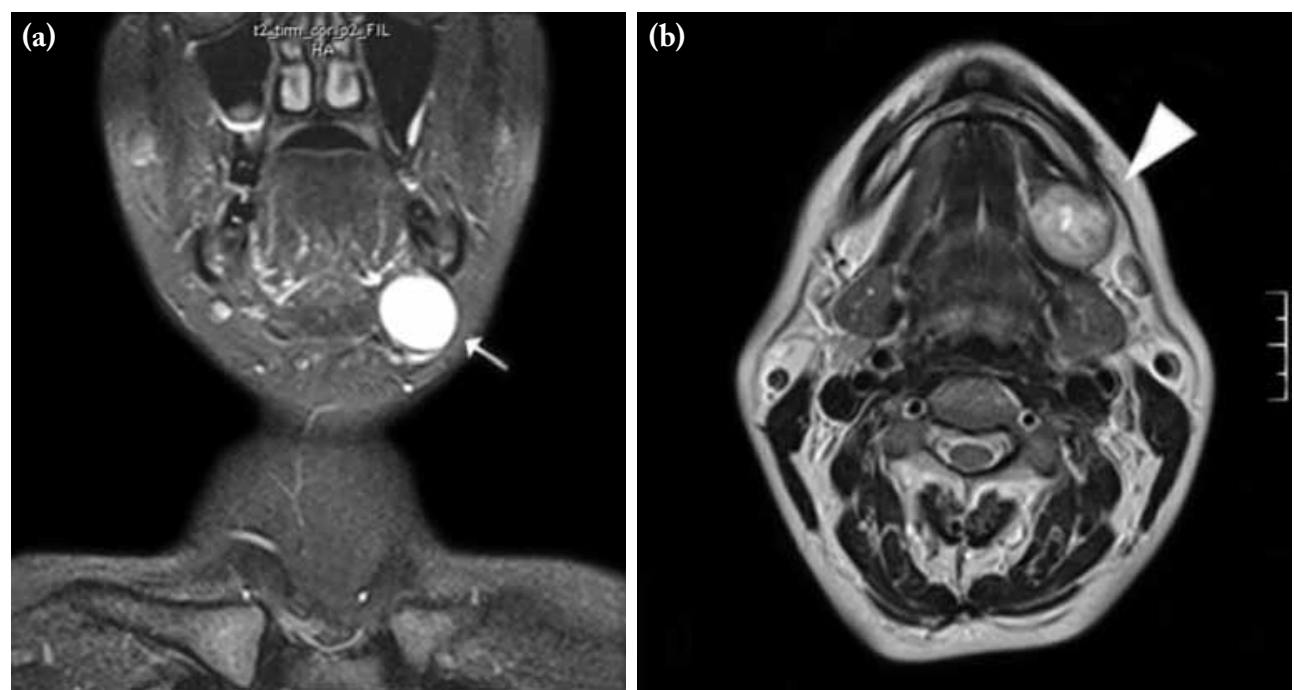

Figure 2. (a) Coronal and (b) axial $\mathrm{T}_{2}$ weighted magnetic resonance imaging views reveal contrastenhanced sharply demarcated $5 \times 5 \mathrm{~cm}$ left submandibular mass. 


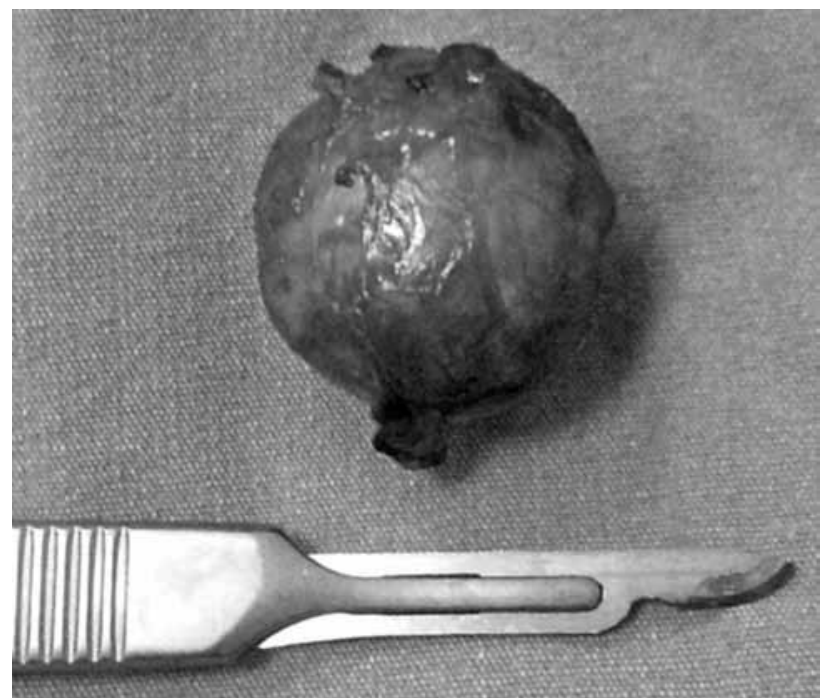

Figure 3. Gross specimen of the extracapsular excised schwannoma.

is the risk of recurrent schwannoma. Therefore, cases treated by intracapsular enuclation should be followedup closely and completion surgery should be performed as needed. In our case there has been no recurrence during one-year follow-up.

Schwannoma, a benign neural sheath tumor, can be seen in cranial nerves. Hypoglossal nerve schwannomas are rarely seen in the head and neck region. Most cases are asymptomatic but can be diagnosed after pathological investigation. The gold standard treatment of choice is tumor excision. Extracapsular excision is a valuable method with preservation of neural function and less risk for recurrence.

\section{Declaration of conflicting interests}

The authors declared no conflicts of interest with respect to the authorship and/or publication of this article.

\section{Funding}

The authors received no financial support for the research and/or authorship of this article.

\section{REFERENCES}

1. Ducatman BS, Scheithauer BW, Piepgras DG, Reiman HM, Ilstrup DM. Malignant peripheral nerve sheath tumors. A clinicopathologic study of 120 cases. Cancer 1986;57:2006-21.

2. Colreavy MP, Lacy PD, Hughes J, Bouchier-Hayes D, Brennan P, O'Dwyer AJ, et al. Head and neck schwannomas-a 10 year review. J Laryngol Otol 2000;114:119-24.

3. Furukawa M, Furukawa MK, Katoh K, Tsukuda M. Differentiation between schwannoma of the vagus nerve (a)
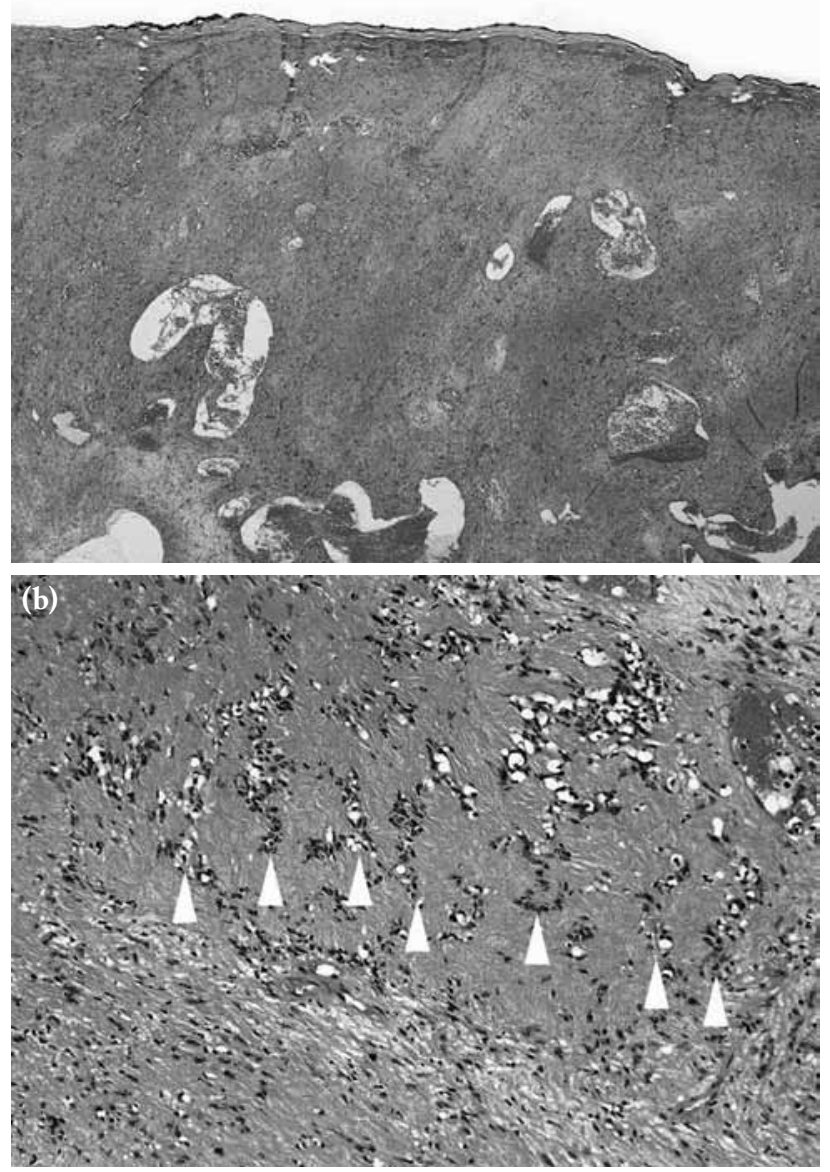

Figure 4. (a) Spindle-shaped cells with hypercellular and hypocellular areas surrounded by a thin capsule composed of fibrous connective tissue ( $\mathrm{H}-\mathrm{E} \mathrm{x} 40$ ). (b) The spindle-shaped cells form palisading nuclei in the fibrillary stroma (arrows) (H-E x 400).

and schwannoma of the cervical sympathetic chain by imaging diagnosis. Laryngoscope 1996;106:1548-52.

4. Chang KC, Leu YS. Hypoglossal schwannoma in the submandibular space. J Laryngol Otol 2002;116:63-4.

5. de Bree R, Westerveld GJ, Smeele LE. Submandibular approach for excision of a large schwannoma in the base of the tongue. Eur Arch Otorhinolaryngol 2000;257:283-6.

6. Liu HL, Yu SY, Li GK, Wei WI. Extracranial head and neck Schwannomas: a study of the nerve of origin. Eur Arch Otorhinolaryngol 2011;268:1343-7.

7. Yörük Ö, Altaş E, Tatar A, Altaş Ş. Hypoglossal schwannoma. KBB ve BBC Dergisi 2010;18:63-6.

8. King AD, A huja AT, King W, Metreweli C. Sonography of peripheral nerve tumors of the neck. AJR Am J Roentgenol 1997;169:1695-8.

9. Kami YN, Chikui T, Okamura K, Kubota Y, Oobu K, Yabuuchi $\mathrm{H}$, et al. Imaging findings of neurogenic tumours in the head and neck region. Dentomaxillofac Radiol 2012;41:18-23. 
10. Tomita T, Ozawa H, Sakamoto K, Ogawa K, Kameyama K, Fujii M. Diagnosis and management of cervical sympathetic chain schwannoma: a review of 9 cases. Acta Otolaryngol 2009;129:324-9.

11. Kang GC, Soo KC, Lim DT. Extracranial non-vestibular head and neck schwannomas: a ten-year experience. Ann Acad Med Singapore 2007;36:233-8.

12. Valentino J, Boggess MA, Ellis JL, Hester TO, Jones RO. Expected neurologic outcomes for surgical treatment of cervical neurilemomas. Laryngoscope 1998;108:1009-13. 